\title{
Hubungan Pengetahuan dan Tindakan Pencegahan Diabetes Mellitus Tipe 2
}

\section{Correlation Between Knowledge And Precaution Diabete Mellitus Type 2}

\section{Limsah Silalahi}

Departemen Promosi Kesehatan dan Ilmu Perilaku, Fakultas Kesehatan Masyarakat, Universitas Airlangga

Email: limsah.silalahi-2016@fkm.unair.ac.id

\begin{abstract}
Background: Diabetes Mellitus Type 2 is the sixth leading cause of death in the world. Diabetes mellitus with complications is the third highest cause of death in Indonesia. East Java Province occupies the largest number of patients with Diabetes Mellitus, which is 605,974 patients. Objective: The purpose of this study is to determine the correlation between knowledge and prevention of Diabetes Mellitus type 2 in Muhammadiyah Senior High School 7 Surabaya. Method: This type of research is quantitative. The design used is cross sectional. The sample of this study was 70 respondents. This research used simple random sampling technique. The independent variable wass knowledge about Diabetes Mellitus, while the dependent variable was prevention of Diabetes Mellitus type 2. Data analysis using the chi square test. Results: The results of this study showed the $p$ value $0,0001<a=0.1$ so that the results of $p<a$. This means that there is a significant relationship between knowledge about diabetes mellitus type 2 and prevention of Diabetes Mellitus type 2 of students Muhammadiyah Senior High School 7 Surabaya. Conclusion: Knowledge of Students Muhammadiyah Senior High School 7 Surabaya is related to efforts to prevent Diabetes Mellitus type 2.
\end{abstract}

Keywords: diabetes mellitus, DM type 2, knowledge, action, precaution

ABSTRAK

Latar Belakang: Diabetes Mellitus Tipe 2 merupakan penyebab kematian nomor 6 di dunia. Diabetes Mellitus dengan komplikasi merupakan penyebab kematian tertinggi ketiga di Indonesia. Provinsi Jawa Timur menempati jumlah perkiraan terbesar penderita Diabetes Mellitus yaitu 605.974 penderita. Tujuan: Tujuan dari penelitian ini untuk mengetahui hubungan antara pengetahuan dan tindakan pencegahan Diabetes Mellitus tipe 2 di SMA Muhammadiyah 7 Surabaya. Metode: Jenis penelitian ini adalah kuantitatif. Desain yang digunakan yaitu cross sectional. Sampel penelitian ini sebanyak 70 responden. Penelitian ini menggunakan teknik simple random sampling. Variabel independen yaitu pengetahuan tentang Diabetes Mellitus, sedangkan variabel dependen adalah tindakan pencegahan Diabetes Mellitus tipe 2. Analisis data menggunakan uji chi square. Hasil: Hasil penelitian ini menujukkan $p$ value $0,0001<a=0,1$ sehingga hasil $p<a$. Hal ini bermakna bahwa terdapat hubungan yang signifikan antara pengetahuan tentang Diabetes Mellitus tipe 2 dengan tindakan pencegahan Diabetes Mellitus tipe 2 pada siswa-siswi SMA Muhammadiyah 7 Surabaya. Kesimpulan: Pengetahuan Siswa-Siswi SMA Muhammadiyah 7 Surabaya berhubungan dengan upaya pencegahan penyakit Diabetes Mellitus tipe 2.

Kata Kunci: diabetes mellitus, DM tipe 2, pengetahuan, tindakan, upaya pencegahan 


\section{PENDAHULUAN}

Penyakit degeneratif merupakan permasalahan kesehatan yang sudah lama dialami beberapa negara di dunia, baik negara maju dan negara berkembang. Penyakit ini disebabkan oleh perubahan gaya hidup. Penyakit diabetes merupakan salah satu dari empat prioritas penyakit tidak menular. Data menyebutkan bahwa 1 dari 2 orang penyandang diabetes belum menyadari bahwa dirinya mengidap diabetes, dimana sebenarnya $80 \%$ kejadian diabetes dapat dicegah. Penyakit diabetes dapat dikontrol dan penderitanya dapat berumur panjang dan hidup sehat (International Diabetes Federation, 2015).

Diabetes mellitus (DM) merupakan suatu penyakit metabolik karena adanya masalah pada pengeluaran insulin. Insulin yang diproduksi oleh pankreas kurang, akibatnya terjadi ketidakseimbangan gula dalam darah sehingga meningkatkan konsentrasi kadar gula darah (Kementerian Kesehatan RI, 2014). Diabetes dapat disebabkan oleh beberapa faktor risiko. Penyebab paling banyak ditemui adalah pola hidup yang tidak sehat. Contoh pola hidup yang tidak sehat yaitu makan makanan yang banyak mengandung gula/lemak, sedikit mengandung karbohidrat dan/serat serta jarang melakukan aktivitas fisik (Soegondo and Sukardji, 2008). Penelitian lain menunjukkan bahwa tingkat pengetahuan dan tingkat pendidikan yang rendah merupakan salah satu penyebab tingginya angka kasus penyakit termasuk DM tipe 2 (Zahtamal, Chandra and Restuastuti, 2007).

Penelitian lain menyebutkan bahwa kebiasaan mengkonsumsi alkohol dan tembakau/rokok, kurangnya melakukan aktivitas fisik serta melakukan diet yang tidak sehat merupakan faktor risiko tertinggi penyakit tidak menular pada remaja. Untuk mencapai status kesehatan yang baik dalam dekade berikutnya, maka diperlukan perilaku pro kesehatan sejak remaja. Perilaku pro sehat akan sangat membantu mencegah timbulnya penyakit tidak menular sejak dini sepeti diabetes mellitus (Isfandari and Lolong, 2014).

Kunci mencegah penyakit DM tipe 2 adalah dengan melakukan pola hidup sehat. Bentuk usaha yang dapat dilakukan sejak remaja yaitu tidak melakukan/meniru kebiasaan dalam masyarakat yang dapat meningkatkan risiko penyakit Diabetes Mellitus (DM) tipe 2. Perilaku remaja sejak dini akan mempengaruhi tingkat kesehatannya dimasa tua nanti. Proporsi remaja di Indonesia pada 2010 sebesar $18 \%$ atau sekitar 43,5 juta jiwa. Sebanyak 426.786 remaja usia 10-19 di Surabaya. Jumlah remaja yang sangat besar memiliki risiko yang sangat besar pula terhadap penyakit diabetes melitus (Badan Pusat Statistik, 2011).

Masa remaja merupakan suatu masa perkembangan dalam kehidupan seorang individu atau tahap kehidupan yang bersifat peralihan dan tidak mantap dalam pegangan nilai, norma dan kepribadian diri. UNICEF tahun 2011 menyebutkan definisi remaja adalah yang berusia 10-19 tahun.

Pola hidup remaja kini cenderung kurang teratur yang berisiko menyebabkan diabetes di kemudian hari. Sebanyak $87 \%$ remaja gemar mengkonsumsi fast food maupun junk food. Remaja pada umumnya lebih tertarik mengkonsumsi makanan dari luar rumah seperi di kantin sekolah dan pedagang kaki lima. Makanan/jajanan yang tersedia di pedagang kaki lima dan kantin sekolah tersebut umumnya mengandung lemak yang tinggi serta rendah akan serat, vitamin dan mineral. Perkembangan teknologi juga menyebabkan berkurangnya aktivitas fisik remaja tersebut (Pramono and Sulchan, 2014).

Pola hidup merupakan kebiasaan yang dilakukan dan dapat berpengaruh terhadap kesehatan seseorang. Penderita DM tipe 2 dianjurkan melakukan aktifitas fisik 30 menit dalam sehari sebanyak 3-4 kali dalam seminggu seperti berjalan kaki dan lari ringan. Seseorang yang jarang melakukan aktifitas fisik mengalami kelebihan energi yang dikonsumsi, karena sedikitnya energi yang dikeluarkan tubuh, sehingga menimbulkan ketidakseimbangan energi yang disimpan pada jaringan adipose. Kondisi ini dapat memicu risiko diabetes mellitus tipe 2 akibat terjadinya resistensi insulin (PB PERKENI, 2011).

Konsumsi sayur dan buah juga dapat mengurangi risiko DM tipe 2 . Rekomendasi untuk konsumsi sayur yaitu 3 porsi/hari, konsumsi buah 2 porsi/hari. 
Manfaat dari mengonsumsi buah dan sayur yaitu menurunkan absorbsi kolesterol dan lemak (Kusno, Kpantov and Ratag, 2015). Tidak merokok dapat mengurangi risiko penyakit diabetes mellitus tipe 2, karena seseorang yang lebih sering terpapar dengan asap rokok lebih berisiko menderita penyakit ini dibanding dengan orang yang tidak/jarang terpapar oleh asap rokok. Kondisi ini disebabkan karena merokok menyebabkan terjadinya resistensi insulin yang menyebabkan meningkatnya kadar gula darah.

Selain faktor fisik, faktor psikososial juga dapat mempengaruhi risiko DM tipe 2. Menurut Shawn Talbott, dijelaskan bahwa pada umumnya individu yang sedang stress cenderung memiliki berat badan berlebih. Orang yang mengalami stres psikososial merupakan salah satu faktor risiko menderita DM (pre-diabetic risk factor).

Upaya pengendalian faktor risiko penyakit DM tipe 2 yang telah dipromosikan adalah aksi CERDIK, yaitu dengan melakukan: 1) Cek kesehatan secara teratur untuk mengendalikan berat badan, periksa tekanan darah, gula darah, dan kolesterol secara teratur, 2) Enyahkan asap rokok dan jangan merokok, 3) Rajin melakukan aktivitas fisik minimal 30 menit sehari, 4) Diet seimbang dengan mengkonsumsi makanan sehat dan gizi seimbang, 5) Istirahat yang cukup dan, 6) Kelola stres dengan baik dan benar (Kementerian Kesehatan RI, 2017).

\section{METODE}

Jenis penelitian ini adalah kuantitatif. Desain yang digunakan adalah desain cross sectional, dengan menggunakan analisa data yaitu analisis univariat dan bivariat dan teknik sampling yang digunakan yaitu simple random sampling. Populasi yang menjadi subyek penelitian adalah seluruh siswa SMAM 7 Surabaya dengan jumlah 237 siswa. Jumlah sampel minimal yang diperoleh berdasarkan perhitungan Slovin adalah 70 responden $\alpha=0,1$. Penelitian ini dilakukan pada bulan Oktober pada tahun 2017.

Survei pendahuluan dilaksanakan di SMA Muhammadiyah 7 Surabaya pada 13 pelajar. Data yang dikumpulkan dalam survei pendahuluan yaitu terkait aktivitas fisik, paparan asap rokok, pola makan, istirahat, dan stress pada siswa dan siswi di SMA Muhammadiyah 7 Surabaya. Pengumpulan data pada survey pendahuluan menggunakan teknik wawancara dan angket. Survey ini dimaksudkan untuk memperoleh gambaran mengenai aktivitas fisik, merokok, pola makan, istirahat, dan stres pada pelajar SMAM 7 Surabaya.

Kesimpulan dari survey pendahuluan tersebut yakni terdapat tiga masalah kesehatan dengan jawaban tertinggi yaitu tidak menjaga pola makan, aktivitas fisik yang kurang, dan terkena paparan asap rokok. Ketiga masalah kesehatan tersebut merupakan faktor risiko terjadinya penyakit diabetes melitus.

Pengumpulan data dilakukan menggunakan instrumen berupa pada kuesioner. Kuesioner tersebut berisi pertanyaan atau pernyataan mengenai karakteristik responden, pengetahuan, dan tindakan responden tentang upaya pencegahan penyakit Diabetes Mellitus tipe 2. Pengetahuan diukur dengan menggunakan pertanyaan benar atau salah, sedangkan tindakan diukur dengan pertanyaan ya atau tidak. Pengetahuan dikatakan baik jika terjawab benar $>75 \%$, cukup 56\%-75\%, dan kurang jika jawaban benar $\leq 55 \%$. Skor item tindakan dikategorikan baik jika skor $>75 \%$, kategori cukup jika skor 56\%-75\% dan kategori kurang jika skor $\leq 55 \%$.

Variabel independen dalam penelitian ini yaitu pengetahuan tentang Diabetes Mellitus tipe 2, sedangkan variabel dependen yaitu tindakan pencegahan Diabetes Mellitus tipe 2. Uji yang digunakan yaitu chi square. Uji chi square dilakukan untuk melihat hubungan antara variabel pengetahuan dan variabel tindakan.

\section{HASIL DAN PEMBAHASAN}

\section{Gambaran}

karakteristik responden disajikan dalam Tabel 1. Tabel 1 menunjukkan bahwa mayoritas responden adalah perempuan (59\%). Hasil ini sejalan dengan penelitian sebelumnya, dimana perempuan cenderung lebih berisiko memiliki penyakit diabetes mellitus dan diabetes gestasional (Diani, Waluyo and Sukmarini, 2013). Dominasi jenis kelamin ini dikaitkan dengan kegemukan yang merupakan pencetus 
Diabetes Mellitus tipe 2 (Soegondo, Soewondo and Subekti, 2009).

Usia responden terbanyak adalah pada rentang 15-19 tahun (96\%). Usia remaja merupakan usia yang tepat untuk melakukan pencegahan tingkat dasar. Ini dilakukan untuk mencegah generasi yang sedang bertumbuh untuk tidak meniru atau melakukan kebiasaan hidup yang tidak sehat yang dapat memicu kesakitan/penyakit (Kurniawan, 2010).

Mayoritas IMT responden berada dalam kelompok normal (36\%). Orang dengan berat badan berlebih memiliki masukan kalori yang berlebih (Sugiritama et al., 2015). Kondisi ini disebabkan karena kelelahan yang dialami oleh sel beta sehingga tidak mampu memproduksi insulin dengan jumlah yang cukup. Produksi insulin yang tidak cukup tidak dapat mengimbangi kelebihan kalori yang masuk. Akibatnya adalah kadar glukosa dalam darah terus meningkat yang akhirnya akan menjadi DM.

Tabel 1. Karakteristik Responden

\begin{tabular}{lll}
\hline \multicolumn{1}{c}{ Karakteristik } & \multicolumn{2}{c}{ Jumlah } \\
\cline { 2 - 3 } & & $\mathbf{n}$ \\
\hline Jenis Kelamin & & \\
\hline Laki-laki & 29 & 41 \\
Perempuan & 41 & 59 \\
\hline Total & 70 & 100 \\
\hline Usia & & \\
\hline 10-14 tahun & 3 & 4 \\
15-19 tahun & 67 & 96 \\
\hline Total & 70 & 100 \\
\hline IMT & & \\
\hline Kurus & 19 & 27 \\
Normal & 25 & 36 \\
Gemuk & 15 & 21 \\
Obesitas & 11 & 16 \\
\hline Total & 70 & 100 \\
\hline Uang saku/hari & & \\
\hline$<$ Rp5.000 & 11 & 16 \\
Rp 6.000-10.000 & 31 & 44 \\
Rp 11.000-15.000 & 5 & 7 \\
$>$ Rp 15.000 & 23 & 33 \\
\hline Total & 70 & 100 \\
\hline
\end{tabular}

Mayoritas responden mendapat uang saku sebesar Rp6.000-10.000 (44\%). Banyak atau sedikitnya uang saku yang didapat responden tidak berpengaruh pada keinginan untuk membeli makanan di luar. Dapat disimpulkan pula bahwa pendapatan tidak berkaitan dengan upaya pencegahan diabetes.

Hasil penelitian tersebut berbeda dengan penelitian lain yang menyatakan bahwa status ekonomi sosial (pendapatan) dapat mempengaruhi konsep pola konsumsi seimbang dari seseorang yang dikaitkan biaya untuk memenuhi kebutuhan. Rendahnya pola konsumsi junk food dapat dipengaruhi oleh pendapatan orang tua responden yang rata-rata dibawah upah minimal regional (Mongisidi, 2014).

Distribusi frekuensi pengetahuan dan tindakan responden tentang diabetes mellitus tipe 2 pada Tabel 2 dikategorikan dalam kategori baik, cukup dan kurang. Hasil pada tabel distribusi 2 menunjukkan, sebagian besar pengetahuan tentang pencegahan diabetes tipe 2 dalam kategori baik (45,7\%). Tabel 2 menunjukkan bahwa sebagian besar tindakan pencegahan diabetes tipe 2 dalam kategori cukup (44,3\%). Tindakan responden cukup baik karena dapat dilihat dimana sebagian besar dari siswa tersebut dibekali pengetahuan tentang Diabetes Mellitus tipe 2 dalam kategori baik.

Tabel 2. Distribusi Frekuensi Pengetahuan tentang Diabetes Mellitus Tipe 2

\begin{tabular}{lcc}
\hline \multirow{2}{*}{ Variabel } & \multicolumn{2}{c}{ Total } \\
\cline { 2 - 3 } & $\mathbf{n}$ & $\%$ \\
\hline Pengetahuan & & \\
\hline Baik & 32 & $45,7 \%$ \\
Cukup & 25 & $35,7 \%$ \\
Kurang & 13 & $18,6 \%$ \\
\hline Total & 70 & $100 \%$ \\
\hline Tindakan & & \\
\hline Baik & 9 & 12,9 \\
Cukup & 31 & 44,3 \\
Kurang & 30 & 42,9 \\
\hline Total & 70 & 100 \\
\hline
\end{tabular}

Hasil analisis berdasarkan Tabel 3 yaitu mayoritas responden (57,1\%) memiliki pengetahuan dan tindakan yang baik. Responden dengan tindakan pencegahan kurang sebanyak 17 responden dari total 70 responden dengan presentase $24,3 \%$. Nilai $X^{2}$ hitung sebesar 21,287 dengan nilai Asymp.sig yaitu 0,0001 . $\quad P$ value $(0,0001)<\mathrm{a}(0,1)$. Kesimpulannya yaitu terdapat hubungan antara pengetahuan dengan tindakan pencegahan DM tipe 2 di SMA Muhammadiyah 7 Surabaya.

\section{Pengetahuan tentang Diabetes Mellitus Tipe 2}

Pengetahuan responden merupakan hal yang penting, karena dengan pemahaman mengenai pengetahuan tersebut, responden dapat menentukan langkah untuk mencegah 
diabetes mellitus. Hasil analisis univariat mengenai pengetahuan responden tentang diabetes mellitus diperoleh hasil bahwa mayoritas responden memiliki pengetahuan tentang diabetes mellitus sudah baik.

Seseorang yang mengenyam bangku pendidikan yang lebih tinggi, memiliki pengetahun yang lebih luas juga, termasuk pengetahuan dalam aspek kesehatan. Pengetahuan yang dimiliki cenderung menimbulkan kesadaran untuk berperilaku sehat. Pengetahuan manusia sebagain besar diperoleh dari pengalaman. Pengalaman tersebut dapat berasal dari orang lain maupun dari diri sendiri.

Pola hidup yang tidak sehat seperti serba instan, canggih, dan santai sebagai akibat timbulnya diabetes. Sebanyak 42 responden dari 70 responden dengan presentase $60 \%$ mengetahui bahwa asap dari rokok berisiko meningkatkan kadar kolesterol dan gula darah, sehingga orang yang terpapar asap rokok berisiko terkena Diabetes Mellitus tipe 2. Sebanyak 54 responden dari 70 responden dengan presentase $77 \%$ mengetahui mengenai waktu makan yang baik dalam sehari adalah 3 kali yakni sarapan, makan siang, dan makan malam. Sebanyak 86\% atau sejumlah 50 responden dari total 70 responden mengetahui bahwa rutin melakukan aktivitas fisik adalah salah satu cara mencegah penyakit Diabetes mellitus tipe 2.

Tabel 3. Hubungan Tentang Pengetahuan dan Tindakan Pencegahan Diabetes Tipe 2 pada Siswa-Siswi SMA M 7 Surabaya

\begin{tabular}{|c|c|c|c|c|c|c|c|c|}
\hline \multirow{3}{*}{$\begin{array}{c}\text { Pengetahuan tentang DM } \\
\text { Tpe } 2\end{array}$} & \multicolumn{4}{|c|}{$\begin{array}{c}\text { Tindakan Pencegahan } \\
\text { DM tipe } 2\end{array}$} & \multirow{2}{*}{\multicolumn{2}{|c|}{ Total }} & \multirow{3}{*}{$\begin{array}{c}X^{2} \\
\text { hitung }\end{array}$} & \multirow{3}{*}{$P$ value } \\
\hline & \multicolumn{2}{|c|}{ Baik } & \multicolumn{2}{|c|}{ Kurang } & & & & \\
\hline & $\mathrm{n}$ & $\%$ & $\mathrm{n}$ & $\%$ & $n$ & $\%$ & & \\
\hline Baik & 40 & 57,1 & 17 & 24,3 & 57 & 81,4 & & \\
\hline Kurang & 0 & 0 & 13 & 18,6 & 13 & 18,6 & 18,517 & 0,0001 \\
\hline Total & 40 & 57,1 & 30 & 42,9 & 70 & 100 & & \\
\hline
\end{tabular}

Semakin tinggi tingkat pendidikan yang ditempuh, maka akan semakin cepat individu tersebut menerima dan memahami informasi yang didapatkan (Budiman and A., 2013). Tingkat pengetahuan dan pendidikan yang rendah adalah salah satu penyebab tingginya kasus suatu penyakit, termasuk Diabetes Mellitus tipe 2. Pengetahuan merupakan hal yang penting untuk membentuk sebuah perilaku. Begitu pula dalam melakukan pencegahan terhadap penyakit diabetes mellitus yang memerlukan pengetahuan berupa pengertian, tanda dan gejala, faktor risiko, dan cara untuk mencegah terjadinya diabetes mellitus itu sendiri. Salah satu sumber pengetahuan dapat diperoleh melalui promosi kesehatan. Contohnya yaitu tersedianya faktor lingkungan yang mendorong perilaku hidup bersih dan sehat, serta juga dapat diperoleh dari pendidikan kesehatan.

Penelitian lain tentang yang dilakukan di Puskesmas Bambanglipuro Bantul Yogyakarta, diperoleh hasil bahwa mayoritas pasien lulusan SLTA memiliki tingkat pengetahuan yang cukup, sedangkan pasien dengan tingkat pendidikan SLTP memiliki tingkat pengetahuan yang kurang. Hasil penelitian tersebut menyimpulkan adanya hubungan signifikan antara pengetahuan pasien mengenai diabetes dengan upaya pencegahan luka dengan aktivitas fisik pada pasien diabetes mellitus tipe 2 (Conceicao, 2017). Seseorang dengan bekal pendidikan yang tinggi diharapkan memiliki pengetahuan yang luas pula, namun kondisi ini tidak bersifat mutlak. Tidak semua orang dengan bekal pendidikan yang rendah memiliki pengetahuan yang rendah pula. Pengetahuan bukan hanya bersumber dari pendidikkan formal, melainkan juga dari non formal. Pengetahuan individu dikatakan baik, cukup, kurang jika mengandung 2 aspek yaitu aspek negatif dan positif. Kedua aspek ini yang akan menentukan pengetahuan manusia (Wawan and Dewi, 2011).

Pengetahuan adalah dasar sebuah tindakan. Sebelum individu bertindak, biasanya didahului dengan tahu, setelah itu mempunyai inisiatif untuk melakukan suatu tindakan. Adanya dasar pengetahuan pada perilaku tertentu 
membuat perilaku tersebut bertahan lebih lama. Pengetahuan sangat dibutuhkan untuk dapat mengubah masyarakat dengan lebih mudah kearah yang lebih baik. "Tahu" merupakan tingkat pengetahuan yang paling rendah, yang artinya mengingat suatu materi yang pernah dipelajari. Mengingat kembali sesuatu materi yang diterima sebelumnya (recall) termasuk termasuk ke dalam "tahu" (Morley, 1999).

\section{Tindakan Upaya Pencegahan Diabetes Mellitus Tipe 2}

Besarnya insiden, prevalensi, dan komplikasi diabetes mellitus menggambarkan betapa pentingnya pencegahan dini terhadap penyakit diabetes mellitus. Adapun cara pencegahannya adalah mengatur pola makan, olah raga, kurangi merokok, dan menurunkan berat badan berlebih (Notoadmojo, 2012). Hasil analisis penelitian yang dilakukan, terdapat 39 responden dari total 70 responden dengan presentase $56 \%$ melakukan upaya pencegahan diabetes mellitus tipe 2 . Upaya pencegahan yang dilakukan yaitu selalu makan teratur 3 kali dalam sehari. Kemudian sebanyak 35 responden dari total 70 responden dengan presentase $50 \%$ melakukan aktifitas fisik seperti olah raga minimal 10 menit dalam satu kegiatan tanpa henti selama lima hari dalam 1 minggu sebagai tindakan upaya pencegahan diabetes mellitus tipe 2 . Sebanyak 53 responden dari total 70 responden dengan presentase $76 \%$ menghindari asap rokok ketika ada anggota keluarga yang merokok.

Pencegahan diabetes melitus tipe 2 juga dipengaruhi oleh faktor sosial ekonomi. Terdapat beberapa alasan yang menjelaskan bahwa status sosial ekonomi yang rendah mempengaruhi tingkat olahraga/aktifitas fisik yang rendah pula, yaitu keterbatasan keuangan dimana diperlukan uang untuk dapat membeli peralatan olahraga untuk menunjang kesehatan, kemudian hidup di lingkungan yang terbatas atau minim sarana/fasilitas olahraga, selain itu kurangnya pengetahuan tentang olahraga dan tidak adanya dukungan sosial untuk berolah raga juga menjadi alasan bahwa status sosial ekonomi rendah mempengaruhi tingkat olahraga. Individu dengan status ekonomi rendah, sedikit mendapatkan saran/nasehat untuk melaksanakan olahraga (Hasbi, 2012).

Pencegahan penyakit DM tipe 2 terdiri dari 4 tingkatan, yakni pencegahan tingkat dasar (primordial preventio), primary prevention yaitu pencegahan tingkat pertama yang meliputi promosi kesehatan dan pencegahan khusus. Secondary prevention atau pencegahan tingkat kedua yakni meliputi diagnosa dini serta pengobatan yang tepat. Tertiary prevention atau pencegahan tingkat ketiga yang meliputi pencegahan terhadap terjadinya cacat dan rehabilitasi (Budiarto and Anggraeni, 2013).

Seluruh responden dalam penelitian ini tergolong dalam usia remaja. Hal ini sesuai dikarenakan sasaran utama pencegahan tingkat dasar (primordial prevention) adalah remaja, baik remaja awal ataupun remaja akhir. Usaha yang dapat dilakukan pada masa remaja yaitu mencegah risiko atau mempertahankan risiko rendah dalam masyarakat terhadap penyakit diabetes mellitus tipe 2. Pencegahan DM tipe 2 dilakukan dengan mempertahankan dan memelihara kebiasaan atau perilaku yang sehat, dimana kebiasaan tersebut dapat mencegah dan menurunkan risiko penyakit diabetes mellitus tipe 2 tersebut. Remaja dapat mengadopsi perilaku yang dapat mencegah risiko diabetes mellitus tipe 2 dengan cara meniru dan mempertahankan kebiasaan masyarakat pedesaan. Kebiasaan tersebut antara lain rutin melakukan aktifitas fisik, mengonsumsi sayuran, dan kurang mengonsumsi lemak hewani, serta kebiasaan-kebiasaan lainnya yang dapat menurunkan risiko penyakit DM tipe 2 .

Penelitian yang membahas tentang gaya hidup pada penderita diabetes mellitus tipe 2 di Semarang menunjukkan hasil bahwa sebagian besar atau sekitar $71,7 \%$ (38 penderita diabetes mellitus) dari total 53 responden melakukan gaya hidup yang sehat. Sebanyak 15 responden $(28,3 \%)$ lainnya dari total 53 responden dengan pola hidup tidak sehat (Hairi, Apriatmoko and Sari, 2013). Kondisi tersebut jelas menunjukan bahwa seseorang mencari informasi terkait kesehatan apabila seseorang tersebut sudah terjangkit penyakit. Gaya hidup sehat penderita DM tipe 2 dalam penelitian tersebut masuk dalam pencegahan tingkat ketiga (tertiary prevention), dikarenakan 
mereka melakukan gaya hidup sehat untuk mencegah terhadap kecacatan akibat penyakit diabetes mellitus tipe 2 . Perilaku gaya hidup sehat penderita diabetes mellitus dalam penelitian tersebut yaitu pengaturan pola makan, pola tidur, aktivitas fisik, konsumsi serat, tidak konsumsi alkohol serta tidak merokok (Paulus, 2012).

Remaja sekarang cenderung melakukan gaya hidup modern yang serba santai, instant, dan canggih. Makin beragamnya jenis makanan yang manis, , dan berkolesterol tinggi serta ditambah dengan adanya teknologi canggih membuat semuanya serba otomatis. Gaya hidup tersebut dapat menjadikan faktor yang meningkatkan individu tanpa riwayat diabetes berisiko terjangkit diabetes melitus tipe 2 (Gustaviani, 2006). Sebagian besar tindakan responden berada dalam kategori cukup. Upaya pencegahan siswa SMA Muhammadiyah merupakan upaya pencegahan tingkat dasar. Diharapkan remaja terus melakukan tindakan upaya preventif tersebut sehingga dapat mencegah dari berbagai penyakit, utamanya yang diakibatkan oleh gaya hidup tidak sehat. Remaja juga diharapkan mampu mencegah timbulnya kebiasaan baru yang tidak sehat dalam masyarakat dan tidak meniru kebiasaan dalam masyarakat yang dapat meningkatkan risiko terserang penyakit diabetes. Tren yang sebaiknya tidak ditiru oleh remaja yaitu trend makan junk food, kecanduan game yang menyebabkan malas beraktivitas, serta tergabung dalam pergaulan yang buruk.

Pola hidup sehat dapat dilakukan remaja dengan beberapa cara. Pertama, menjaga pola makan. Menjaga pola makan dapat dilakukan dengan mengatur asupan karbohidrat dalam setiap makanan yang dimakan, mengonsumsi makanan gizi sehat dan seimbang, menghindari mengonsumsi makanan yang berkolestrol tinggi atau siap saji. Konsumsi makanan yang bergizi dan seimbang merupakan hal yang penting untuk mencegah penyakit diabetes melitus tipe 2. Kedua, melakukan kebiasaan olah fisik atau olah raga yang bermanfaat untuk tubuh dan peredaran darah. Hal yang terpenting dalam olah raga adalah rutin dan terusmenerus dan tetap mengontrol berat badan. Olahraga tidak harus yang berat, namun sebaiknya rutin. Ketiga, tidak atau berhenti merokok, karena merokok dapat meningkatkan risiko diabetes mellitus tipe 2.

Dalam Faktor internal dan eksternal merupakan faktor yang berpengaruh terhadap suatu perilaku (Notoadmojo, 2005). Kecerdasan, emosi, persepsi, pengetahuan, motivasi, dan lain-lain yang berfungsi mengolah rangsangan dari luar merupakan faktor internal. Lingkungan sekitar (fisik dan non fisik), seperti kebudayaan dalam masyarakat, keadaan sosial ekonomi, iklim dan manusia merupakan faktor ekstern (Notoadmojo, 2005).

Perilaku didasari oleh tiga faktor yaitu faktor predisposisi, pendukung, dan pendorong. Faktor predisposisi yaitu terdiri dari pengetahuan, kepercayaan, sikap, faktor demografi, dan sebagainya. Faktor pendukung meliputi tersedianya sumber daya atau potensi masyarakat seperti lingkungan fisik serta fasilitas kesehatan. Faktor pendorong meliputi sikap dan perilaku orang lain seperti petugas kesehatan, tokoh masyarakat.

Perilaku untuk mencegah penyakit diabetes dipengaruhi oleh beberapa faktor. Pertama, faktor predisposisi. Faktor ini terdiri dari pengetahuan yang dimiliki oleh individu terkait penyakit diabetes dan risiko bila sudah terjangkit penyakit diabetes. Kepercayaan juga mempengaruhi individu untuk melakukan tindakan upaya pencegahan. Kepercayaan individu pada bahaya yang dapat terjadi pada dirinya bila terjangkit penyakit tentunya mempengaruhi individu untuk melakukan upaya pencegahan. Kedua, faktor pendukung. Faktor ini dilatar belakangi ada tidaknya fasilitas yang dapat mendukung individu untuk melakukan upaya pencegahan penyakit diabetes mellitus. Keberadaan fasilitas olahraga seperti Gelanggang Olah Raga (GOR), tersedianya area jogging, serta area umum lain untuk berolahraga. Faktor pendukung lain yaitu adanya fasilitas kesehatan seperti klinik, praktik dokter, puskesmas dan rumah sakit. Keberadaan faktor pendukung tersebut tentunya akan memudahkan individu untuk mencegah diabetes mellitus. Ketiga, faktor pendorong. Faktor pendorong dilatarbelakangi oleh sikap dan perilaku orang lain yang ada disekitar individu. Individu yang tinggal di daerah yang mayoritas masyarakatnya melakukan 
olahraga rutin cenderung juga berperilaku demikian. Kondisi ini karena individu tersebut terpengaruh oleh perilaku orang lain. Motivasi dari tenaga kesehatan dan keluarga juga dapat menjadi pendorong individu melakukan upaya kesehatan. Contohnya, tenaga kesehatan dan keluarga memberi motivasi untuk rutin cek kesehatan.

\section{Hubungan Pengetahuan dengan Tindakan Pencegahan Diabetes Mellitus Tipe 2}

Pengetahuan yang dimiliki oleh individu dapat mempengaruhi seseorang dalam berperilaku. Hal ini dikarenakan individu yang memiliki pengetahuan akan dapat mengetahui apa yang dibutuhkan, serta mampu mengatasi atas kebutuhan hidupnya (Karyoso, 1999). Terbentuknya suatu perilaku yang baru berawal dari pengetahuan (kognitif), artinya seseorang mengetahui materi terlebih dulu kemudian pengetahuan tersebut akan membentuk sikap dan tindakan (Karyoso, 1999). Pengetahuan dan pemahaman tentang penyakit diabetes melitus akan membentuk perilaku atau tindakan apa yang akan dilakukan untuk mencegah penyakit diabetes melitus (Effendi and Makhfudli, 2009).

Hasil penelitian oleh menunjukkan, dimana 42 responden (60\%) mengetahui bahwa asap rokok dapat meningkatkan kadar gula darah, sebanyak 53 responden (76\%) melakukan tindakan upaya pencegahan diabetes. Tindakan pencegahan yang dilakukan yaitu menghindari asap rokok ketika ada yang merokok di dalam rumah. Sebanyak 50 responden (71\%) yang mengetahui bahwa melakukan aktivitas fisik secara rutin adalah salah satu upaya mencegah diabetes. 36 responden $(51 \%)$ melakukan upaya pencegahan diabetes tipe 2 dengan rajin berolahraga. 54 responden (77\%) mengetahui upaya pencegahan yaitu dengan makan 3 kali dalam sehari yakni sarapan, makan siang dan makan malam, dan 39 (56\%) melakukan upaya tersebut yaitu dengan makan sehari 3 kali sehari untuk mencegah penyakit diabetes melitus tipe 2 .

Tingkat pengetahuan mempengaruhi perilaku. Pendidikan, tradisi atau kebiasaan dalam mayarakat serta pengalaman hidup mempengaruhi perubahan perilaku seseorang yang sesuai dengan kesehatan (Notoadmojo, 2012).
Pendapat ini sesuai dengan hasil penelitian yang dilakukan, dimana mayoritas responden memiliki pengetahuan baik memiliki upaya pencegahan yang baik pula.

Hasil analisa data menunjukkan, terdapat hubungan bermakna antara tingkat pengetahuan tentang diabetes mellitus tipe 2 dengan tindakan pencegahan diabetes mellitus tipe 2 . Ini menunjukan kelompok responden dengan pengetahuan yang rendah memiliki upaya pencegahan yang kurang, sedangkan kelompok responden dengan pengetahuan yang baik memiliki tindakan pencegahan yang baik juga.

Penelitian sebelumnya yang membahas tentang pengetahuan, sikap dan tindakan pada remaja terhadap faktor risiko penyakit diabetes mellitus tipe 2 menyebutkan bahwa mayoritas responden memiliki tingkat pengetahuan dan tindakan yang baik. Kondisi ini menunjukan adanya keterkaitan antara pengetahuan dan tindakan pada responden (Moon, 2017). Penelitian tersebut serupa dengan penelitian lain yang menyimpulkan terdapat hubungan antara pengetahuan dengan upaya pencegahan faktor risiko diabetes mellitus (Khairani, Nugrahalia and Sartini, 2016).

Pengetahuan, sikap, dan tindakan
memiliki keterkaitan dan saling mempengaruhi satu dengan yang lain. Tingkat pengetahuan dapat mempengaruhi sikap dan tindakan seseorang (Achmadi, 2013). Tindakan responden yang baik terkait aktivitas fisik dapat dipengaruhi karena individu tersebut juga mempunyai bekal pengetahuan yang baik pula (Moon, 2017).

Tingkat kesadaran yang baik dipengaruhi oleh pengetahuan masyarakat yang baik pula tentang diabetes mellitus tipe 2. Pengetahuan merupakan hal mendasar untuk menyadarkan masyarakat berperilaku sehat, sehingga deteksi dini dari gejala yang di timbulkan akan diketahui. Deteksi dini diabetes mellitus adalah tindakan awal sebagai upaya kemungkinan terkena diabetes mellitus secara dini agar dapat ditangani secara memadai, sehingga kesakitan/komplikasi dapat dicegah. Deteksi dini dapat dilakukan oleh seseorang apabila mempunyai tanda dan gejala yang meliputi perubahan berat 
badan yang terus bertambah melebihi berat badan ideal, gejala-gejala lain seperi sering kencing, sering minum dan sering makan. Apabila terdapat tanda dan gejala tersebut, maka perlu dilakukan pemeriksaan lebih cepat atau secara dini diabetes mellitus melalui skrining dengan pemeriksaan kadar gula darah sewaktu.

\section{SIMPULAN}

Terdapat hubungan yang signifikan antara pengetahuan tentang DM tipe 2 dengan tindakan pencegahan DM tipe 2 pada siswa-siswi SMA Muhammadiyah 7 Surabaya.

\section{DAFTAR PUSTAKA}

Achmadi, U. F. (2013) Kesehatan Masyarakat Teori dan Aplikasi. Jakarta: Rajawali Pers.

Badan Pusat Statistik (2011) Sensus Penduduk Tahun 2010. Jakarta.

Budiarto, E. and Anggraeni, D. (2013) Pengantar Epidemiologi. 2nd edn. Jakarta: EGC.

Budiman and A., R. (2013) Kapita Selekta Kuisioner Pengetahuan dan Sikap Dalam Penelitian Kesehatan. Jakarta: Salemba Medika.

Conceicao, A. Da (2017) Hubungan Pengetahuan Tentang Diabetes Melitus Dengan Perilaku Pencegahan Luka Pada Aktivitas Fisik Pasien DM Tipe 2 Di Puskesmas Bambanglipuro Bantul Yogyakarta. Universitas Jenderal Ahmad Yani.

Diani, N., Waluyo, A. and Sukmarini, L. (2013) 'PENGETAHUAN KLIEN TENTANG DIABETES MELITUS TIPE 2 Pendahuluan Metode', Jurnal Keperawatan Indonesia, 16(2), pp. 120-127.

Effendi, F. and Makhfudli (2009) Keperawatan Kesehatan Komunitas: Teori dan Praktek Dalam Keperawatan. Jakarta: Salemba Medika.

Gustaviani, R. (2006) Diagnosis dan Klasifikasi Diabetes Melitus, Buku Ajar Ilmu Penyakit Dalam. 3rd edn. Edited by S. Suyono. Jakarta: Balai Penerbit FKUI.

Hairi, L., Apriatmoko, R. and Sari, L. (2013) 'Hubungan Antara Tingkat Pengetahuan Tentang Diabetes Mellitus Dengan Gaya Hidup
Penderita Diabetes Melitus Tipe II di Desa Nyatnyono, Kecamatan Ungaran Barat,Kabupaten Semarang', Jurnal Kesehatan, 5.

Hasbi, M. (2012) ANALISIS FAKTOR YANG BERHUBUNGAN DENGAN KEPATUHAN PENDERITA DIABETES MELITUS DALAM MELAKUKAN OLAHRAGA DI WILAYAH KERJA PUSKESMAS PRAYA LOMBOK TENGAH. Universitas Indonesia.

International Diabetes Federation (2015) IDF Diabetes Atlas. 6th edn. International Diabetes Federation.

Isfandari, S. and Lolong, D. B. (2014) 'Analisa Faktor Risiko dan Status Kesehatan Remaja Indonesia pada Dekade Mendatang', Buletin Penelitian Kesehatan, 4(2), pp. 122-130.

Karyoso, S. (1999) Pengantar Komunikasi Perawat. Jakarta: EGC.

Kementerian Kesehatan RI (2014) Situasi dan Analisis diabetes. Jakarta.

Kementerian Kesehatan RI (2017) Profil Kesehatan Indonesia 2016. Jakarta.

Khairani, Nugrahalia, M. and Sartini (2016) 'Hubungan Katarak Sneilis dengan Kadar Gula Darah pada Penderita Diabetes Mellitus di Medan', Jurnal Biologi Lingkungan, Industri, Kesehatan, 2(2), pp. 110-116.

Kurniawan, I. (2010) 'Diabetes Melitus Tipe 2 pada Usia Lanjut', Majalah Kedokteran Indonesia, 60(12), pp. 576-584.

Kusno, F. A., Kpantov, N. H. and Ratag, B. T. (2015) 'Hubungan antara Status Sosial Ekonomi dengan Kejadian Diabetes Melitus Tipe 2 di Poliklinik Interna Rumah Sakit Umum Daerah (Rsud) Bitung Tahun 2015. Manado', Media Kesehatan, 7(4), pp. 1-8.

Mongisidi, G. (2014) Hubungan Antara Status Sosio-Ekonomi dengan Kejadian Diabetes Melitus Tipe 2 di Poliklinik Interna BLU RSUP Prof. Dr. R. D. Kandou manado. Manado.

Moon, R. B. (2017) Pengetahuan, Sikap, dan Tindakan terhadap Pola Hidup terkait Faktor Risiko Diabetes Melitus Tipe 2 pada Remaja di Kecamatan Mantrijeron Yogyakarta. 
232 Jurnal Promkes: The Indonesian Journal of Health promotion and Health Education Vol. 7 No. 2 Desember 2019 : 223 - 232, doi: 10.20473/jpk.V7.12.2019.223-232

Universtas Sanata Dharma.

Morley, D. (1999) Prioritas Pediatri di Negara Sedang Berkembang. Jakarta: Yayasan Esentia Medica.

Notoadmojo, S. (2005) Promosi kesehatan dan Perilaku Kesehatan. Jakarta: RIneka Cipta.

Notoadmojo, S. (2012) Promosi kesehatan dan Perilaku Kesehatan. Jakarta: RIneka Cipta.

Paulus (2012) Gambaran Tingkat Pengetahuan Faktor Risiko Diabetes Mellitus pada Mahasiswa Fakultas Ekonomi Universitas Indonesia. Universitas Indonesia.

PB PERKENI (2011) Konsensus Pengolahan dan Pencegahan Diabetes Melitus Tipe 2 di Indonesia. PB PERKENI.

Pramono, A. and Sulchan, M. (2014) 'Kontribusi makanan jajan dan aktivitas fisik terhadap kejadian obesitas pada remaja di kota Semarang', JURNAL GIZI INDONESIA. JURNAL GIZI INDONESIA, (Vol 2, No 2 (2014)), pp. 59-64. Available at: http://ejournal.undip.ac.id/inde x.php/jgi/article/view/8613.

Soegondo, S., Soewondo, P. and Subekti, I. (2009) Penatalaksanaan diabetes melitus terpadu. Jakarta: Balai Penerbit FKUI.

Soegondo, S. and Sukardji, K. (2008) Hidup secara mandiri dengan diabetes melitus, kencing manis, sakit gula. Jakarta: Balai Penerbit.

Sugiritama, I. W. et al. (2015) GAMBARAN IMT (INDEKS MASSA TUBUH) KATEGORI BERAT BADAN LEBIH DAN OBESITAS PADA MASYARAKAT BANJAR DEMULIH,KECAMATAN SUSUT, KABUPATEN BANGLI. Denpasar.

Wawan, A. and Dewi, M. (2011) Teori dan Pengukuran Pengetahuan, Sikap, dan Perilaku Manusia. Yogyakarta: Nuha Medika.

Zahtamal, Chandra, F. and Restuastuti, T. (2007) 'Faktor-faktor Risiko Pasien Diabetes Melitus', Berita Kedokteran Masyarakat, 23(3), pp. 142-147. 